\section{HSE}

Historia Social y de la Educación

Social and Education History
Hipatia Press

www.hipatiapress.com

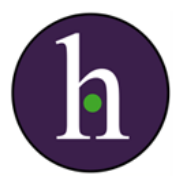

Instructions for authors, subscriptions and further details:

http://hse.hipatiapress.com

\title{
A History of childhood
}

Marta Font ${ }^{1}$

1) Universitat Rovira i Virgili (Spain)

Date of publication: June $23^{\text {rd }}, 2018$

Edition period: Edition period: June 2018-October 2018

To cite this article: Font, M. (2018). A history of childhood [Review of the book]. Social and Education History 7(2), 198-200. doi:

10.17583/hse.2018.3301

To link this article: http://dx.doi.org/10.17583/hse.2018.3301

\section{PLEASE SCROLL DOWN FOR ARTICLE}

The terms and conditions of use are related to the Open Journal System and to Creative Commons Attribution License (CC-BY). 


\section{Reviews (I)}

Pal Adam, I. (2016). A history of childhood. Cambridge, Uk: Polity Press.

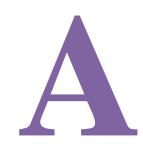

$\mathrm{s}$ the title of the book exposes, its main goal is to present and describe the changes in the concepts of "children" and "childhood" in the west countries from Medieval to Modern Times, through the analysis of the particular nature of childhood along the ages. The book is structured in three sections and twelve chapters, which address the main characteristics of childhood and their evolution, the discoveries of modernity and the main contributions of the 20th Century, which have set the bases of new conceptions towards a long childhood and adolescence.

The first section "Changing conceptions of childhood" presents the differences and similarities observed when analyzing artistic, religious and scientific approaches of childhood from the middle ages to the $20^{\text {th }}$ century, as well as the main related discoveries, their causes and consequences. The first chapter "Conceptions of childhood in the middle ages" aims to evidence that, despite the existing tendencies that deny the role of children in the middle ages, the current notion of childhood is rooted in this medieval conception.

In the second chapter "The quest for a turning point", the author provides evidences of how the enlightenment's discoveries represented a shift in the conception of childhood, promoting general interest in children development and promoting the general prolongation of this stage.

Chapter 3 "Some themes in the cultural history of childhood" is focused on the evolution of certain aspects traditionally associated to childhood, such as innocence, depravity, dependence and nurture.

The second part of the book "Growing up in the Family" provides an indepth analysis of the role of children within the family, their interactions with other relatives and particularities of their daily life. 
Chapter 4 "The start of a new life" is a historical approach to the desire of children and how the reduction in the number of children per family was associated with the higher importance attributed to their wellbeing.

The chapter "A precarious Infancy" presents the main barriers towards the ideal development of childhood through history, centered on some of the causes of children mortality: nourishment, hygiene and child rearing difficulties, infanticide and child abandonment.

The next chapter "Early Childhood, age two to seven" draws a global landscape of the traditional characteristics of this first stage, highlighting the relation between children and their main caregivers, such as mothers, fathers, further relatives and nurses, children's first education and early training focused in hygiene, walking and talking.

Finally, the chapter "Later Childhood, age seven to fourteen" analyzes further relations with parents, emphasizing domestic labors' distribution, children' contribution to family economy, marriage and home leaving.

The last section of the book "Children in a wider world" summarizes children's role outside their family circle, addressing topics as employment, education and health. The first chapter in this section "Children at work in agricultural societies" exposes the main occupations of children in agrarian and proto-industrial sectors: household for girls, workshop apprentices for boys and fruit gathering and animal feeding for both. In these contexts, children employment was uncontroversial, as it was characterized by helping their parents in light tasks.

The following chapter "Child labour and industrialization" draws a complementary narration of the previous one, as when steel and textile industry reached occidental countries, children exploitation was increased and intensified, with risky jobs in factories that disturbed children's health and welfare.

Chapter 10, entitled "Children's Leisure activities" is focused on the influence of socialization and peer-interactions on their further personal development. It also presents the main leisure activities, such as reading, sport, joining youth movements and drama societies. 
In the chapter "Children's health" the improvements in children health and reduction of mortality are deeply analyzed, mainly caused by better nutrition practices and living conditions which derived to the persistence of economic and social inequalities.

Lastly, the chapter "The child and the school" is oriented towards the shift from labor to school world, which represented the cornerstone of the current conception of childhood. In this chapter, the progress from the earlier workshop apprenticeship to national educational systems is considered the main cause of the improvement, not only in children's cultural level, but also in their physical condition and social welfare.

Summarizing, the book describes the main changes in the lives of children, specially accentuated since the industrialization which led to an increasing on the occidental economy and, consequently to an improvement on the living conditions of most children. Thus, children became healthier and happier, attended school and joined leisure activities with other children, reaching better living conditions and further possibilities of personal success.

Marta Font

Universitat Rovira i Virgili marta.font@estudiants.urv.cat 